\title{
Editorial
}

\section{The Stigma of Extremism on Muslims}

It is a fact that the majority of Muslims are peace-loving citizens, who do not share or condone the motives, objectives, and activities of the violent minority. The former may not even hesitate to declare the latter as "not Muslims" due to their activities that are boldly antithetical to basic Islamic teachings and worldview. That would be, understandably, a religiopolitical perspective. But theologically - it is not advisable, nor indeed, effectual to consider not as Muslim, anyone who truly believes in oneness of God, commits himself to following Prophet Muhammad (ȘAAS) and actually performs the fundamentals of Islam, deviation and perversion notwithstanding. On the other hand, those extremist minority - a fraction of the 7 percent of the global Muslim population considered to be "politically radicalized," including sympathizers ${ }^{1}$ - will surely consider their majority detractors not "true and sincere" Muslims. They certainly don't believe the majority has the religious and moral authority over them. Unfortunately, from this perspective, the extremists remain, admittedly, part and parcel of Muslim fold - regardless of whether or not the majority will accept it. And from this perspective of identity and actions that I will contend that not only are the extremists an inescapable nuisance, they remain a regrettable stigma that effects the larger Muslim majority.

In early 2011, when Gabrielle Giffords, the Arizona State Representative was shot in Tucson, Arizona and was severely injured, and twelve others were injured, and six others were killed - I heard about it on the National Public Radio while driving on my way to the mosque. When I told the imam of our local mosque about what just happened, before I said anything about the suspect, he said, "O God, do not let this be by a Muslim." Some non-Muslim readers may wonder why wasn't the imam's immediate concern be about the victims who were injured or killed - rather 
than the identity of the suspect? As Muslims witness and have been forced to live through the backlash of terrorist activities on Muslim communities in America and around the world, the reaction of the imam was understandable, and frankly justified. This type of reaction, by the way, was not an index of any indifference to such a tragic event. In fact, many Muslims have felt the same way about this and other incidents - such as the attack on the February 26, 1993 bombing of the North Tower of the World Trade Center, the attack on the Alfred P. Murrah Federal Building in Oklahoma City resulting in 168 deaths, the attack on September 11, 2001, the Fort Hood shootings - and the injuries to and death of many people in Iraq, Yemen, Afghanistan, London, Madrid, and Tanzania. Although, the imam's prayer came true for that particular tragic incident - the suspect was not a Muslim - that has not been the case for many Muslims who made the same prayers during other terrorist attacks throughout the past decade. What is significant about this story is that Muslims are doubly upset with terrorist attacks; they have concerns for the actual victims - whose majority, worldwide, is Muslim - and for themselves as potentially accidental victims of such tragedies, as well as for their religion, which always wrongly gets bashed and blamed for allegedly inspiring such activities. Once again, from this perspective, Islamic extremism is a tragic plague and an unfortunate stigma.

\section{Muslim Extremists}

Muslim extremism is both religious and political. It is, therefore, needless to say that Muslims have no monopoly on extremist tendencies or terrorism. The terrorist activities of al-Qa'ida (al-Qaeda), the Taliban, Boko Haram, and other individuals represent Islamic extremism - the same way some Jewish assassins like Yigal Amir (the Talmudic student who killed Israeli Prime Minister Yitzhak Rabin) represent Jewish extremists; as well as in the same manner the Hutaree, David Koresh, and Timothy McVeigh represent Christian extremism. ${ }^{2}$ Ironically, a purely political and a non-religious group, the LTTE (Tamil Tigers) holds the record for suicide bomb attacks. ${ }^{3}$

But what is the essence of Islamic extremism - and for that matter, other forms of extremism? Beside some external factors - such as political, economic, and social, always invoked by the extremists as justification ${ }^{4}$ - Islamic extremism is a combination of psycho-religious ideologies and tendencies that drive individuals or groups to hold extreme views or carry out violent activities. These tendencies cut across educational, economic, and generational lines. The following is an explanation of a specific example. 


\section{Intolerance}

Whether they agree or not, all extremists exhibit a high level of intolerance of the "other." Characterized by the feeling of "totalitarianism," this highdegree of intolerance can become markedly dangerous. For the extremists believe their religious position or political stance to be the only viable and authentic one. Hence, any other position becomes so objectionable and its adherents so evil that all possible, even if fatal, means must be deployed to combat their enemies. Once again, the violent manifestation of extremism. Barring all conspiracy theories, the Sunni-Shi'a tit-for-tat attacks during the U.S. invasion of Iraq were classic demonstrations of high level of intolerance of each other's religious, political, and social positions. In their perception, Al-Qaida's attacks on the United States and its allies, were a result of their intolerance of the U.S. foreign policy in the Middle East (justifying it by the U.S. support for Israel and for Arab dictators) ${ }^{5}$

Based on anything but cowardice (as commonly portrayed), the reactions of the extremists out of intolerance are usually inconsiderate, shallowly reasoned, exclusively justified, and morally pretentious. For instance, by declaring war against the United States and attacking its institutions, al-Qa'ida were utterly inconsiderate of the negative impact on the larger human population, including Muslim communities around world. Their reasoning (not reasons) for embarking on the attacks has always been narrow-minded, one-dimensional - and at the same time, petty. Their justification (which they do well to convey for more recruits), while not shared by the majority of Muslims, was exclusivist for their fellow-minded terrorist clique. And all the hype and claims of "defending" Islam and Muslims are largely pretentious. For Muslims - which al-Qa'ida claims to care for worldwide -have fallen victim to al-Qa'ida's atrocities more than nonMuslims.

In the end, no positive result can be shown for all of what al-Qa'ida did. Instead, the backlash to Muslims around the world for al-Qa'ida's activities have been difficulties, a hard life, suspicion, and scrutiny. There has not been a single change in the U.S. foreign policy regarding the Middle East. In other words, as far as Muslims are concerned, al-Qa'ida has not achieved any positive result for their offensive actions.

A high level of intolerance is, arguably, the most destructive force in the equation of extremism. This intolerance not only permeates all types of extremism - religious, political, ethnic, tribal, and so forth - but it also undergirds all sorts of violent activities. Otherwise, being convinced that somebody is wrong or bad, while at the same time tolerating him, will never lead to violence against him. 
However, intolerance is also demonstrated by diverse entities, including governments. The sad reality is that powerful and dominant authorities may also engage in the culture of intolerance, leading to all kinds of violent acts against innocent individuals and groups. Admittedly, this type of intolerance is exclusively political, but may be portrayed as something else. And due to the intolerance of their opposition, governments of the majority Muslim nations engage in atrocities for their own survival. Although in varying degrees, this, again, is not unique to the Muslim world. Human right activists would argue that waterboarding, ${ }^{6}$ exacted by the U.S. security apparatus on al-Qa'ida operatives was an extremist, violent, and cruel act - which, in the context of intolerance, was an attempt to stamp out al-Qa'ida and its objectionable activities.

Truth be told, there is another level of intolerance within the Muslims communities around the world. Though mild, sometime subtle and less destructive, it also poses a constant challenge to Muslims as they aspire to live up to the expectation of Islamic solidarity. This is intra-secterian extremism - in which, for instance, Sunni Muslims from a particular school of law (madhhab) display a sense of intolerance of another school. Depending on several factors - such as the level of concentration of a particular group in an area, the attitudes of leaders in each group, and a history of interaction among groups - the negative effects of this intolerance may or may not be noticed. In America, some East Asian followers of a Shāfi'̄̄ school of law may feel uncomfortable praying behind an imam who is following a Māliki practice. The irony is that ignorance and intolerance blind them from recognizing that Imam al-Shāfi' 1 was himself a student of Imam Mālik. Perhaps due to the lack of political dimension, this is a negligible and manageable problem; yet, it shows that there is a sense of religious extremism at different levels - and still another manifestation of intolerance.

Whether in the case of a severe or mild intolerance, the extremism demonstrated as a consequence feeds on the degree of religious zeal and the convictions of individuals or groups. Although intolerance alone can do a considerable damage, this is an added element that exacerbates the actions of the extremists through an elevated sense of religious duty. In other words, because they believe they are right - based on their narrow scriptural interpretation - on a particular issue, and because they feel they are divinely obligated to carry out or prevent an action, nothing else matters and nothing should stop them - even, if in the end as it usually is, it means violating other Islamic rules and going against the basic goals they 
set for themselves. This explains, but does not not justify why the Muslim extremists, with a clear conscience (if they truly have one), could bomb a mosque full of worshippers during a Friday prayer - and this rationalization to themselves is an explanation that would never make sense to anybody but themselves. Their level of intolerance is high, their zeal strong, and their sense of duty profound. No combination of sentiments could be more deadly. In this scenario, their actions, sadly and regrettably, are unstoppable. What could be a more irritating horror and colossal stigma for the majority of peace-loving Muslims? Nothing.

Whether or not the majority of Muslims can do anything to wipe out this stigma is uncertain. In the first place, they would need a matching sense of duty and a whole lot of politically, economically, and socially preemptive measures put in place. It seems nothing can be done to dissuade the intolerant tendencies of the extremists. But far from military operations, a lot of appropriate democratization, economic reforms, freedom, and respect for citizens, could be done to destabilize the activities of extremists, discourage their recruitments and, in the long run, undercut their appeal. Unfortunately, all this would need an undiluted sincerity, unbroken resolve and serious commitment from Muslims, and from their leaders and government authorities across the board - a proposition, I regret to say, that is easier said than done.

For on their part, majority of peace-loving Muslims have themselves been kept captives to the activities of the extremists. So other than declare their disgust, demonstrate and speak against extremism -and all this they did - they cannot be expected to actually fight back. Specifically, scholars, religious and public opinion leaders around the world have been doing their part to reveal the horror and deviation of the extremists, by issuing fatwas and discouraging Muslims against extremism. ${ }^{7}$ The problem lies with the government authorities of Muslim nations in their efforts to combat extremism. Being charged themselves of some form of intolerance against the opposition, their efforts mimic those of the Western world, where military options are the preferred ones. They have neglected the fact that war creates war; that trying to wipe out extremism by military force is an illusion; and that they are reinforcing the extremists' resolve for violence. So until the preemptive measures suggested above are honestly pursued, extremism will remain a potent stigma for Muslims and a cogent distraction for the world at large. 


\section{This Issue}

We open this first issue of 2012 AJISS with Sultana Afroz's "The Role of Islam in the Abolition of Slavery and in the Development of British Capitalism." She maintains that scholars, while emphasizing European abolitionist movements, have disregarded the role played by the Muslim leadership in West Africa in bringing an end to the transatlantic trade in Africans. Afroz insists that the jiha $\bar{d}$ movements in West Africa in the late-eighteenth century gave political unity to West Africa and challenged the collaboration of European trade in Africans with the pagan slave traders. She concludes that the human resources and the immense wealth of the Moghul India and Imperial China helped develop the British industrial capitalism.

Next is "In Diplomatic Banquet of Treaty: Islamic Shari'"ah and International Laws Share the Attires of Pacta Sunt Servanda," written by Hamzah Adesola Dawood. He contends that treaties under Islamic law and modern international law are based on good faith. Dawood also insists that treaties provide a veritable opportunity to attempt a harmony and communality between two legal regimes with the goal to achieve a common universal understanding that ensures peace and cooperation across the globe.

Jan A. Ali follows with "Contemporary Islamic Revivalism: Key Perspectives." Ali explores the diverse explanations of a contemporary Islamic revivalism. However, the paper focuses on the crisis perspective, the success perspective, and the crisis of modernity perspective to arrive at a more analytical understanding of this important sociological phenomenon.

We close this section of articles with "Islamic Awakening and its Role in Islamic Solidarity in Malaysia," written by Saodah Abd. Rahman and Abu Sadat Nurullah. The authors conclude that the Islamic Awakening in Malaysia has brought about the consciousness of adopting and practicing the Islamic way of life. In this study, the authors seek to highlight the accomplishment of Islamic Awakening in Malaysia, through a tri-dimensional perspective - that is, socioeconomic well-being, the strength of the expansion of Islamic education, and political stability.

The Forum section of this issue contains two contributions, one short and the other long. We begin with Charles E. Butterworth's short piece on "Questions about Roger Scruton," in which he sheds light on Roger Scruton's deliberate conflating of Islam with radical Islam and his attacks on Muslims as though all were Islamists. Butterworth accuses Scruton of "blatant errors," and of ignoring that "there are many faces of Islam varying in place and time as well as social milieu." 
The second paper is "A Survey of Four Indo-Pakistani Scholars' Perspectives on the Islam-Democracy Discourse," by Tauseef Ahmad Parray. Parray presents the arguments, views, opinions, and writings of four prominent living Muslim intellectuals of India and Pakistan who favor theIslamdemocracy compatibility theory. They all lay emphasis on the cocept of $s h \bar{u} r \bar{a}$ as the main and basic foundation and source of democratic ethics in Islam.

Finally, I hope that together, these fantastic essays will not only present our readers with thought-provoking ideas, but inspire in them the intellectual passion to actively participate in the ongoing debates on an array of issues.

In the coming months, we are expecting to publish a "call for papers" for the 2013 AJISS special issue on the "Islamists and the State: New Paradigms and Engagements." Based on what is happening politically in the Muslim world today, we hope for papers that would address specific issues surrounding the current changes and attempts to changes in the Muslim world, both theoretically and practically.

\section{Notes}

1. John Esposito and Dalia Mugahed, Who Speaks for Islam?: What a Billion Muslims Really Think (New York: Gallup Press, 2007), 6970.

2. Gene Te Selle, "Thinking About Religious Extremism," www. witherspoonsociety.org/religious_extremism.htm; "US "Christian Miitants' Charged After FBI Raids,” http://news.bbc.co.uk/2/hi/ americas/8593975.stm.

3. Laurence R. Iannaccone \& Eli Berman, "Religious Extremism: The Good, the Bad, and the Deadly." (Prepared for a Special Issue of Public Choice on the "Political Economy of Terrorism.") Edited by Charles Rowley, 2, http://econ.ucsd.edu/ elib/rex.pdf; Chronology of Suicide Bomb Attacks by LTTE Tamil Tiger Terrorists in Sri Lanka. http://news.bbc.co.uk/2/hi/americas/8593975.stm.

4. Gilles Kepel and Jean-Pierre Milelli, eds., Al-Qaeda in Its Own Words, trans. Pascale Ghazaleh (Cambridge, MA \& London: Harvard University Press, 2008), 47-50 and 195.

5. Ibid.

6. According to the current U.S. Defense Secretary Leon Panetta, waterboarding is a "torture and it's wrong." "CIA Chief: Waterboarding Aided Bin Laden Raid," http://today.msnbc.msn. com/id/42880435/ns/today-today_news/t/cia-chief-waterboardingaided-bin-laden-raid/\#.TzQwxMh-FvA. 
7. Shila Musaji, "Muslim Voices - Part I - Fatwas \& Statements by Muslim Scholars \& Organizations," (updated 12/24/2011), http:// theamericanmuslim.org/tam.php/features/articles/muslim_voices_ against_extremism_and_terrorism_part_i_fatwas/.

Zakyi Ibrahim, Ph.D., Editor, AJISS, Department of Comparative Religion, California State University, Fullerton. zibrahim@fullerton.edu. 